MY APPROACH

\title{
Optimal processing of bone marrow trephine biopsy: the Hammersmith Protocol
}

\author{
K N Naresh, I Lampert, R Hasserjian, D Lykidis, K Elderfield, D Horncastle, N Smith, W Murray- \\ Brown, G W Stamp
}

J Clin Pathol 2006;59:903-911. doi: 10.1136/icp.2004.020610

Specimens of bone marrow trephine biopsy (BMT) are transported and fixed in acetic acid-zinc-formalin fixative, decalcified in $10 \%$ formic acid- $5 \%$ formaldehyde and processed with other specimens to paraffin-wax embedding. Sections, 1- $\mu \mathrm{m}$-thick, are cut by experienced histotechnologists and used for haematoxylin and eosin, Giemsa, reticulin silver and other histological stains.

Further, all immunohistochemical procedures used in the laboratory, including double immunostaining, can be used on these sections with no or minimal modifications. About 10000 BMT specimens have been analysed using this procedure since 1997 and diseases involving the bone marrow have been classified successfully. More recently, standardised polymerase chain reaction-based analysis and mRNA in situ hybridisation studies have been conducted. Excellent morphology with good antigen, DNA and RNA preservation is offered by the Hammersmith Protocol.

See end of article for authors' affiliations

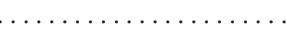

Correspondence to: K N Naresh, Department of Histopathology, Hammersmith Hospital, Du Cane Road, London W12 OHS, UK;

k.naresh@imperial.co.uk

Accepted for publication 9 February 2006
A bone marrow trephine biopsy (BMT) is carried out to assess various haematological problems, particularly in those cases where assessment of marrow cellularity, cell distribution and relationship between different cell types is crucial. It is also important in disease processes that are focal in nature and in those vessels and marrow stroma. In some disorders, the pattern of infiltration provides additional prognostic information. Furthermore, in cases where immunohistochemistry is required and where antigen expression has to be evaluated in spatial contexts, BMT specimens have a major role. Their role is critical in cases of "dry tap", where examination of an aspirate has been unsuccessful owing to a fibrotic or infiltrative process.

In many laboratories standard tissue fixation and sectioning with routine decalcification results in BMT specimens which are difficult to interpret and where immunohistochemical staining can be compromised. Tissue morphology is influenced by the quality of the sample taken (haemorrhage and crush artefact can destroy even the most exquisitely processed sample), the length and type of fixation, the tissue processing programme, the tissue sectioning and the quality of the staining. The presence of bone in BMT that are associated with changes in bone, blood specimens requires decalcification or the use of special blades that can cut un-decalcified bony tissues. Decalcification represents an additional variable influencing the staining pattern, with deterioration in the preservation of cytoplasmic granules and enzyme activity. More importantly, antigenicity in immunohistochemistry may be adversely affected, although the adverse effects can be mitigated by the use of antigen-retrieval techniques. ${ }^{1}$ Resin embedding and cutting with tungsten carbide knives can result in improved cytomorphology. This, however, hinders immunohistochemical procedures for several antigens and is an additional investment of time, expertise and effort for histopathology or haematopathology laboratories. ${ }^{2}$

Routine formalin fixation followed by ethylene diamine tetra acetate (EDTA) or nitric acid decalcification are in common use, but improved methods of fixation and decalcification have also been used to obtain improved tissue morphology in the paraffin-wax-embedded BMT specimens as an alternate to resin embedding. Compared with formalin fixation, mercurial fixatives such as B5 and Zenker's fixative result in improved morphology. ${ }^{3}$ The use of these fixatives is, however, limited by the procedures associated with, and the expense of disposing of, the mercury-containing solutions. In the UK, the Control of Substances Hazardous to Health stipulates that, whenever possible, processes using less harmful substances should substitute for processes using toxic substances such as mercury. A more recent study compared B5 fixation with five other fixatives and showed that acetic acid-zinc-formalin (AZF) provided overall staining and morphological detail comparable to B5 staining. The AZF fixative resulted in superior antigen preservation, and the RNA and DNA were also found to be well preserved for in situ hybridisation (ISH) and molecular analysis. $^{4}$

At the Hammersmith Hospital, London, UK, we have used AZF fixative for more than 10000 BMT specimens since 1997. We standardised a protocol for handling BMT specimens, where, after the initial fixation and decalcification, BMT specimens can be treated similar to other biopsy specimens. We believe that this has been highly successful in terms of providing excellent cytomorphology with haematoxylin and eosin (H\&E)

Abbreviations: AZF, acetic acid-zinc-formalin; BMT, bone marrow biopsy using trephine; EBV, Epstein-Barr virus; EDTA, ethylene diamine tetra acetate; $H \& E$, haematoxylin and eosin; ISH, in situ hybridisation 
and Giemsa stains. Further, the results of other histochemical stains and immunohistochemistry are comparable to those of other biopsy specimens.

\section{BONE MARROW PROCESSING AND STAINING Fixative}

The AZF (zinc chloride, 12.5 g; concentrated formaldehyde, $150 \mathrm{ml}$; glacial acetic acid, $7.5 \mathrm{ml}$; and distilled water, to $1000 \mathrm{ml}$ ) is prepared in bulk and aliquotted into 20-ml universal containers with corrosive hazard labels. These aliquots are sent to the haematology departments and other inpatient and clinic locations where BMTs are carried out. The haematologist is instructed to place the freshly obtained BMT specimens directly into AZF fixative and transport it immediately to the histopathology department, on the same day as the procedure.

\section{Fixation}

Once received in the laboratory, the BMT specimens are left to fix in AZF overnight. The next morning (after 20-24 h), the solution is decanted (with a strainer) and the biopsy specimen is washed in distilled water for $30 \mathrm{~min}$. Specimens from the previous day, received in the histopathology department, having already been fixed in AZF overnight, are similarly treated.

\section{Decalcification}

The water is replaced by Gooding and Stewart's decalcification fluid ( $10 \%$ formic acid and 5\% formaldehyde). The biopsy specimens are left to decalcify for about $6 \mathrm{~h}$ before being processed and embedded in paraffin wax, with procedures similar as for other specimens.

\section{Tissue sectioning and staining}

Sections, $1-\mu \mathrm{m}$ thick (microtome set for $1 \mu \mathrm{m}$ sections), are cut from the paraffin-wax blocks with the routine rotary microtomes in the laboratory. The sections are stained with H\&E, Giemsa, Perl's (iron) and reticulin (silver) stains. Additional unstained sections are placed on poly-L-lysinecoated slides for immunostaining as necessary.

\section{Immunohistochemistry}

Immunohistochemistry panels are used based on the clinical diagnosis, and the required number of sections for each panel (including those required for controls) is cut at the time of initial sectioning. Sections, $1-\mu \mathrm{m}$ thick, are placed on poly-Llysine-coated glass slides. The dewaxed sections are subjected to antigen-retrieval procedures as per the requirements for different antigens. Table 1 gives the details of the antigenretrieval procedures and other details of the individual protocols. The antigen localisation is carried out using Super Sensitive TM Immunohistochemistry Detection System (Biogenex, California, USA), with diaminobenzidine as the final substrate. The automated system developed by Biogenex has been used in most cases. Immunostaining is carried out on the automated system on most occasions and manually on some occasions. We also carry out sequential double immunostaining using previously described methods. ${ }^{5}$ For the second procedure, we use vector blue, amino ethylcarbazole or diaminobenzidine as chromogens.

\section{In situ hybridisation}

ISH of mRNA is carried out using $\kappa$ and $\lambda$ Probe ISH Kit and Epstein-Barr Virus (EBV) Probe ISH Kit according to the manufacturer's instructions (Vision Biosystems Newcastle upon Tyne, UK; Novocastra, Newcastle upon Tyne, UK). For the purposes of probe penetration, proteinase- $\mathrm{K}$ digestion is used before hybridisation. The procedure includes hybridisation for $4 \mathrm{~h}$ at $37^{\circ} \mathrm{C}$ with fluorescein-conjugated oligonucleotide probes. After hybridisation and post-hybridisation washes, probe localisation is carried out using rabbit $\mathrm{F}\left(\mathrm{ab}^{\prime}\right)$ anti-fluorescein isothiocyanate or alkaline phosphatase. Nitro blue tetrazolium or 5-bromo-4-chloro-3-indolyl phosphate is used as substrate to produce a blue-black signal. To ensure optimal mRNA preservation in a given case, a poly-dT probe (instead of the light chain or the EBV probe) on a separate section of the paraffin-wax block is used as a control.

\section{DNA extraction and PCR}

The protocol followed for the BMT specimens is the same as that previously used for paraffin-wax sections of lymphoreticular tissues. Two $15-\mu$ m-thick paraffin-wax sections are cut from the paraffin-wax block on a rotary microtome into a $2 \mathrm{ml}$ Eppendorf tube. Precautions are taken to avoid tissue contamination from other cases. DNA is extracted using the Qiagen DNA Tissue Kit (Gmbh, Frankfurt, Germany). The procedure includes dewaxing, followed by overnight proteinase- $\mathrm{K}$ digestion at $55^{\circ} \mathrm{C}$ in a water bath. After addition of absolute ethyl alcohol, the digests are passed through a DNeasy Mini spin column. The DNA is then eluted from the

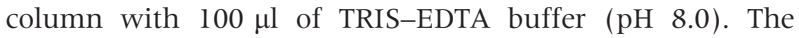
quality of amplifiable DNA is assessed using primers designed to amplify a $200 \mathrm{bp}$ fragment of the $\beta$-actin gene (forward primer 5'CAACTACTCGGGAGGCTGAG3' and reverse primer $5^{\prime}$ GCCCCTGGTAGTTTTTCACA3'). Samples are then subjected to other PCR-based molecular diagnostic assays. For the purpose of this paper, BMT specimens were tested for immunoglobulin heavy chain rearrangement with primers directed at the variable heavy (FR3) region (5'ACACGGCGTGTGTGATATTACTGT3') and the JH regions (5'TGAGGAGACGGTGACCAGGATCCCTTGGCCCCAG3'). The samples were subjected to 40 cycles of amplification on a PCR protocol of $30 \mathrm{~s}$ at $94^{\circ} \mathrm{C}, 30 \mathrm{~s}$ at $52^{\circ} \mathrm{C}$ and $30 \mathrm{~s}$ at $72^{\circ} \mathrm{C}$, after an initial denaturation for $5 \mathrm{~min}$ at $94^{\circ} \mathrm{C}$. The analysis ended with a final extension at $72^{\circ} \mathrm{C}$ for $10 \mathrm{~min}$. The PCR products were run on a 3\% agarose gel, stained with ethidium bromide and photographed under UV illumination. Cases with clonal rearrangements resulted in an amplicon of around $100 \mathrm{bp}$.

\section{RESULTS AND COMMENTS}

For optimal interpretation of BMT specimens, a combination of excellent cytomorphology, provision to use the full range of immunohistochemical stains, preservation of mRNA to carry out ISH analyses and the ability to extract DNA of a quality sufficient to carry out PCR-based analyses are all crucial. Although it is generally accepted that resin embedding and semithin sections provide the best morphology, there have been questions on preservation of antigens and nucleic acids. ${ }^{2}{ }^{6}$ Several papers deal with these issues and confirm adequate antigen and DNA preservation in resinembedded BMT specimens. ${ }^{7-10}$ However, RNA preservation and suitability for ISH analyses of mRNA is not clear. The main criticism of this procedure is the requirement of specialised technology and skill and the additional costs associated with it.

The principles of our approach are as follows:

1. Excellent morphology without compromising preservation of antigens and nucleic acids

2. Preservation of antigen and nucleic acid

3. Simple and integrated, with standard processing schedules

4. Inexpensive and non-toxic.

\section{Optimal morphology without compromising} preservation of antigens and nucleic acids

Our primary intention was to standardise a protocol for processing BMT specimens, which would result in cytomorphology of a quality comparable to that of resin-embedded 
Table 1 Antibodies used on bone marrow trephine biopsy specimens at the Hammersmith Hospital

\begin{tabular}{|c|c|c|c|}
\hline Antibody & Dilution & Antigen retrieval & Source \\
\hline Glycophorin C & $1: 200$ & $20 \min \mathrm{MW}$, citrate $\mathrm{pH} 6.0$ & Dako \\
\hline Myeloperoxidase & 1:2000 & No treatment & Dako \\
\hline CD61 & $1: 10$ & $10 \mathrm{~min} \mathrm{MW}$, citrate $\mathrm{pH} 6.0$ & Dako \\
\hline CD42b & $1: 500$ & 20 min $\mathrm{MW}$, citrate $\mathrm{pH} 6.0$ & Novocastra \\
\hline Mast cell tryptase & $1: 3000$ & $10 \min \mathrm{MW}$, citrate $\mathrm{pH} 6.0$ & Dako \\
\hline Neutrophil elastase & $1: 200$ & 10 min Trypsin & Dako \\
\hline Tdt & $1: 50$ & $20 \mathrm{~min} \mathrm{MW}$, citrate $\mathrm{pH} 6.0$ & Novocastra \\
\hline CD117 & $1: 400$ & $10 \mathrm{~min} \mathrm{MW}$, citrate $\mathrm{pH} 6.0$ & Dako \\
\hline CD34 & $1: 100$ & 20 min $M W$, citrate $\mathrm{pH} 6.0$ & Dako \\
\hline CD31 & $1: 10$ & $10 \mathrm{~min} \mathrm{MW}$, citrate $\mathrm{pH} 6.0$ & Dako \\
\hline Factor VIII & $1: 1000$ & 10 min Trypsin & Dako \\
\hline CDla & $1: 200$ & $20 \mathrm{~min} \mathrm{MW}$, citrate $\mathrm{pH} 6.0$ & Novocastra \\
\hline CD2 & $1: 50$ & 20 min EDTA, pH 8.0 & Novocastra \\
\hline CD3 & $1: 50$ & 20 min EDTA, pH 8.0 & Novocastra \\
\hline CD4 & $1: 400$ & 20 min EDTA, pH 8.0 & Novocastra \\
\hline CD5 & $1: 50$ & 20 min EDTA, pH 8.0 & Novocastra \\
\hline CD7 & $1: 50$ & $20 \min \mathrm{MW}$, citrate $\mathrm{pH} 6.0$ & Novocastra \\
\hline CD8 & $1: 50$ & 20 min EDTA, pH 8.0 & Novocastra \\
\hline CD10 & $1: 20$ & 20 min EDTA, pH 8.0 & Novocastra \\
\hline CD15 & $1: 10$ & $20 \min \mathrm{MW}$, citrate $\mathrm{pH} 6.0$ & Dako \\
\hline CD20 & $1: 250$ & $20 \mathrm{~min} \mathrm{MW}$, citrate $\mathrm{pH} 6.0$ & Dako \\
\hline CD21 & $1: 50$ & 15 min Trypsin & Dako \\
\hline CD23 & $1: 100$ & $20 \min \mathrm{MW}$, citrate $\mathrm{pH} 6.0$ & Novocastra \\
\hline CD25 & $1: 100$ & $20 \mathrm{~min} \mathrm{MW}$, citrate $\mathrm{pH} 6.0$ & Novocastra \\
\hline CD30 & $1: 50$ & 20 min Dako retrieval solution, $\mathrm{pH} 6.0$ & Dako \\
\hline CD38 & $1: 50$ & 20 min EDTA, pH 8.0 & Novocastra \\
\hline CD43 & $1: 10$ & $20 \min \mathrm{MW}$, citrate $\mathrm{pH} 6.0$ & Novocastra \\
\hline CD45 (LCA) & $1: 10$ & 20 min EDTA, pH 8.0 & Dako \\
\hline CD45RO & $1: 100$ & $20 \mathrm{~min} \mathrm{MW}$, citrate $\mathrm{pH} 6.0$ & Dako \\
\hline CD56 & $1: 100$ & $20 \min \mathrm{MW}$, citrate $\mathrm{pH} 6.0$ & Novocastra \\
\hline CD57 & $1: 40$ & $20 \min \mathrm{MW}$, citrate $\mathrm{pH} 6.0$ & Becton Dickinson \\
\hline CD68 & $1: 700$ & $10 \mathrm{~min} \mathrm{MW}$, citrate $\mathrm{pH} 6.0$ & Dako \\
\hline CD68 & $1: 50$ & $10 \min \mathrm{MW}$, citrate $\mathrm{pH} 6.0$ & Dako \\
\hline CD79a & $1: 20$ & 20 min $\mathrm{MW}$, citrate $\mathrm{pH} 6.0$ & Dako \\
\hline CD99 & $1: 25$ & $10 \mathrm{~min} \mathrm{MW}$, citrate $\mathrm{pH} 6.0$ & Dako \\
\hline CD138 & $1: 100$ & $20 \mathrm{~min} \mathrm{MW}$, citrate $\mathrm{pH} 6.0$ & Serotec \\
\hline $\mathrm{Bcl}-2$ & $1: 7$ & $20 \mathrm{~min} \mathrm{MW}$, citrate $\mathrm{pH} 6.0$ & Dako \\
\hline $\mathrm{Bcl}-6$ & $1: 20$ & 20 min EDTA, pH 8.0 & Dako \\
\hline Cyclin-D1 & $1: 50$ & $20 \min \mathrm{MW}$, citrate $\mathrm{pH} 6.0$ & \\
\hline Perforin & $1: 20$ & $20 \mathrm{~min} \mathrm{MW}$, citrate $\mathrm{pH} 6.0$ & Novocastra \\
\hline Granzyme-B & $1: 20$ & $20 \min \mathrm{MW}$, citrate $\mathrm{pH} 6.0$ & Novocastra \\
\hline Alk & $1: 10$ & $\begin{array}{l}20 \text { min Dako retrieval } \\
\text { solution, } \mathrm{pH} 9.9\end{array}$ & Dako \\
\hline HLA-DR & $1: 100$ & 20 min $\mathrm{MW}$, citrate $\mathrm{pH} 6.0$ & Dako \\
\hline DBA44 & $1: 100$ & $20 \mathrm{~min} \mathrm{MW}$, citrate $\mathrm{pH} 6.0$ & Dako \\
\hline TRAP & $1: 100$ & $20 \mathrm{~min} \mathrm{MW}$, citrate $\mathrm{pH} 6.0$ & Novocastra \\
\hline vs $38 \mathrm{C}$ & $1: 100$ & $20 \mathrm{~min} \mathrm{MW}$, citrate $\mathrm{pH} 6.0$ & ICRF \\
\hline Mum-1 & $1: 200$ & $20 \mathrm{~min} \mathrm{MW}$, citrate $\mathrm{pH} 6.0$ & Santa Cruz \\
\hline Pax-5 & $1: 400$ & $20 \mathrm{~min} \mathrm{MW}$, citrate $\mathrm{pH} 6.0$ & Santa Cruz \\
\hline Lysozyme & $1: 3000$ & No treatment/10 min trypsin & Dako \\
\hline$\kappa$ & $1: 10,000$ & No treatment & Dako \\
\hline$\lambda$ & $1: 10,000$ & No treatment & Dako \\
\hline $\lg G$ & $1: 3000$ & 10 min Trypsin & Dako \\
\hline $\lg M$ & $1: 300$ & 20 min Trypsin & Dako \\
\hline $\lg D$ & $1: 400$ & $20 \mathrm{~min} \mathrm{MW}$, citrate $\mathrm{pH} 6.0$ & Dako \\
\hline $\lg A$ & $1: 1000$ & 10 min Trypsin & Dako \\
\hline $\lg E$ & $1: 50$ & 10 min Trypsin & Dako \\
\hline EBV-LMP-1 & $1: 50$ & $10 \mathrm{~min} \mathrm{MW}$, citrate $\mathrm{pH} 6.0$ & Novocastra \\
\hline $\mathrm{HHV}-8$ & $1: 50$ & $20 \mathrm{~min} \mathrm{MW}$, citrate $\mathrm{pH} 6.0$ & Novocastra \\
\hline Parvovirus & $1: 800$ & $10 \min \mathrm{MW}$, citrate $\mathrm{pH} 6.0$ & Novocastra \\
\hline Broad range keratin & $1: 150$ & 10 min Trypsin & Dako \\
\hline EMA & $1: 100$ & $20 \mathrm{~min} \mathrm{MW}$, citrate $\mathrm{pH} 6.0$ & Dako \\
\hline HMFG1 & $1: 800$ & No treatment & ICRF \\
\hline HMFG2 & $1: 50$ & No treatment & Novocastra \\
\hline GCDFP* & $1: 100$ & $20 \mathrm{~min} \mathrm{MW}$, citrate $\mathrm{pH} 6.0$ & Novocastra \\
\hline ER & $1: 200$ & 20 min EDTA, pH 8.0 & Novocastra \\
\hline PR & $1: 100$ & $20 \mathrm{~min} \mathrm{MW}$, citrate $\mathrm{pH} 6.0$ & Biogenix \\
\hline PSA & $1: 2000$ & No treatment & Dako \\
\hline TTF-1 & $1: 50$ & $20 \min \mathrm{MW}$, citrate $\mathrm{pH} 6.0$ & Novocastra \\
\hline PCNA & $1: 50$ & No treatment & Novocastra \\
\hline Ki-67 & $1: 50$ & $20 \min \mathrm{MW}$, citrate $\mathrm{pH} 6.0$ & Novocastra \\
\hline p53 & $1: 50$ & $10 \mathrm{~min} \mathrm{MW}$, citrate $\mathrm{pH} 6.0$ & Novocastra \\
\hline Mcm-2 & $1: 50$ & $20 \mathrm{~min} \mathrm{MW}$, citrate $\mathrm{pH} 6.0$ & Gift from Dr Dilworth \\
\hline Chromogranin* & $1: 200$ & No treatment & Biogenix \\
\hline Synaptophysin* & $1: 40$ & $20 \mathrm{~min} \mathrm{MW}$, citrate $\mathrm{pH} 6.0$ & Dako \\
\hline Vimentin* & $1: 1000$ & No treatment & Sigma \\
\hline S100* & $1: 1000$ & No treatment & Dako \\
\hline Desmin* & $1: 25$ & $20 \mathrm{~min} \mathrm{MW}$, citrate $\mathrm{pH} 6.0$ & Dako \\
\hline Melan $\mathrm{A}^{*}$ & $1: 50$ & $20 \mathrm{~min} \mathrm{MW}$, citrate $\mathrm{pH} 6.0$ & Novocastra \\
\hline
\end{tabular}




\begin{tabular}{|c|c|c|c|}
\hline Antibody & Dilution & Antigen retrieval & Source \\
\hline HMB45* & $1: 50$ & No treatment & Dako \\
\hline $\mathrm{CK} 7^{*}$ & $1: 25$ & $10 \min \mathrm{MW}$, citrate $\mathrm{pH} 6.0$ & Dako \\
\hline CK20* & $1: 100$ & 10 min Trypsin & Dako \\
\hline Thyroglobulin* & $1: 1000$ & No treatment & Dako \\
\hline Cálcitonin* & $1: 800$ & No treatment & Novocastra \\
\hline Myoglobin* & $1: 500$ & No treatment & Dako \\
\hline \multicolumn{4}{|c|}{$\begin{array}{l}\text { EBV, Epstein-Barr virus; EDTA, ethylene diamine tetra acetate; EMA, epithelial membrane antigen, ER, oestrogen } \\
\text { receptor; LMP, latent membrane protein; MW, microwave; PCNA, proliferating cell nuclear antigen; PSA, prostate } \\
\text { specific antigen; PR, progesterone receptor. *Rarely performed on bone marrow trephines. Manufacturer details } \\
\text { are as follows: Dako (Carpinteria, California, USA); Novocastra (Newcastle upon Tyne, UK); Becton Dickinson } \\
\text { (Franklin Lakes, New Jersey, USA); Santa Cruz (Raleigh, North Carolina, USA); Biogenix (Herffordshire, UK); } \\
\text { Sigma (Perth, Western Australia, Australia). }\end{array}$} \\
\hline
\end{tabular}
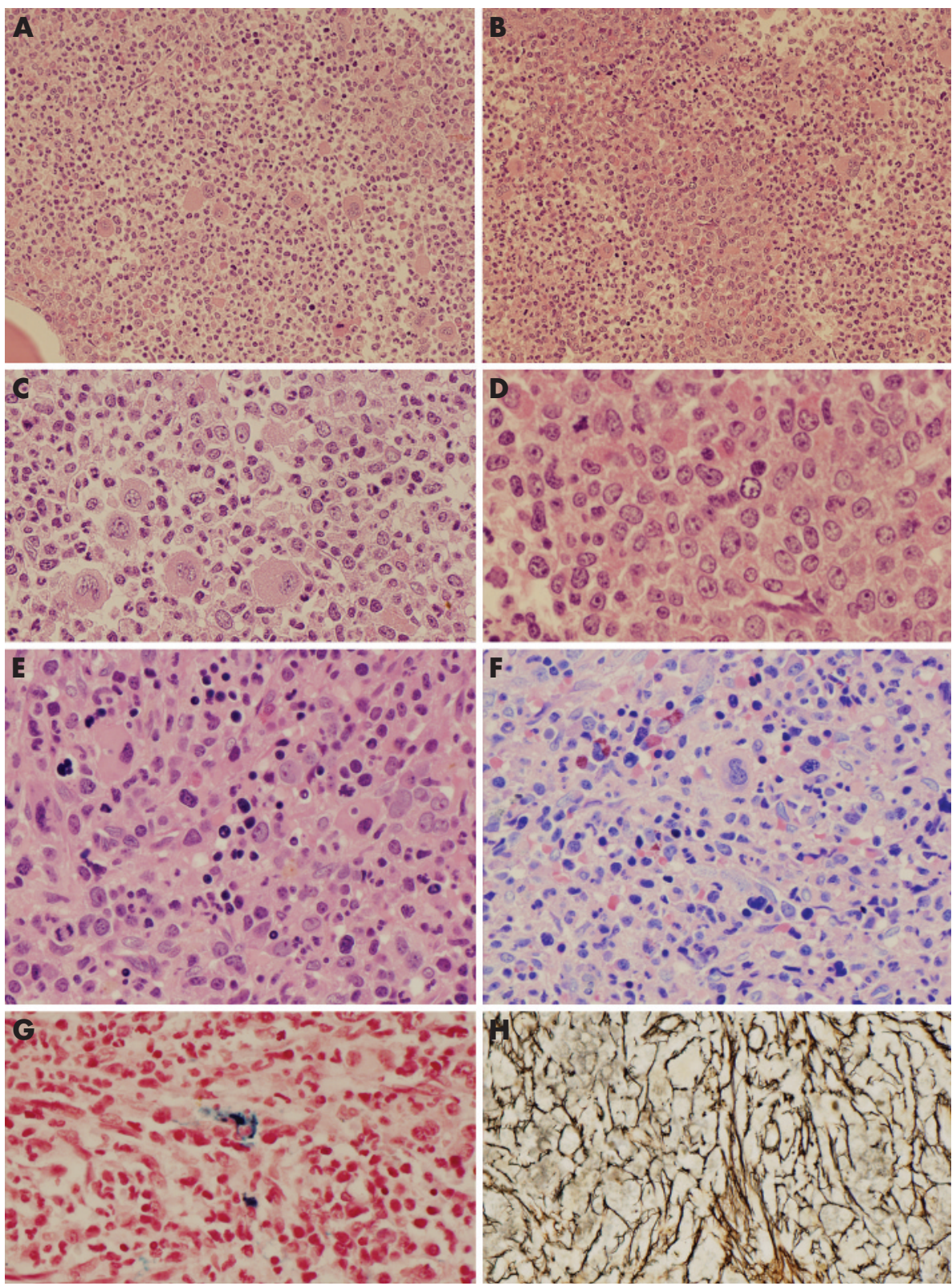

Figure 1 (A-D) Haematoxylin and eosin (H\&E) section of chronic myeloid leukaemia (A) $\times 40 ;(C) \times 200$ with foci of abnormal localisation of immature precursors; (B) $\times 100$; (D) $\times 400$. (E-H) Myeloproliferative disorder with dysplastic features. (E) H\&E staining, $\times 200 ;(F)$ Geimsa, $\times 200 ;(G)$ Perl's, $\times 200 ;(H)$ silver/reticulin, $\times 200$. 

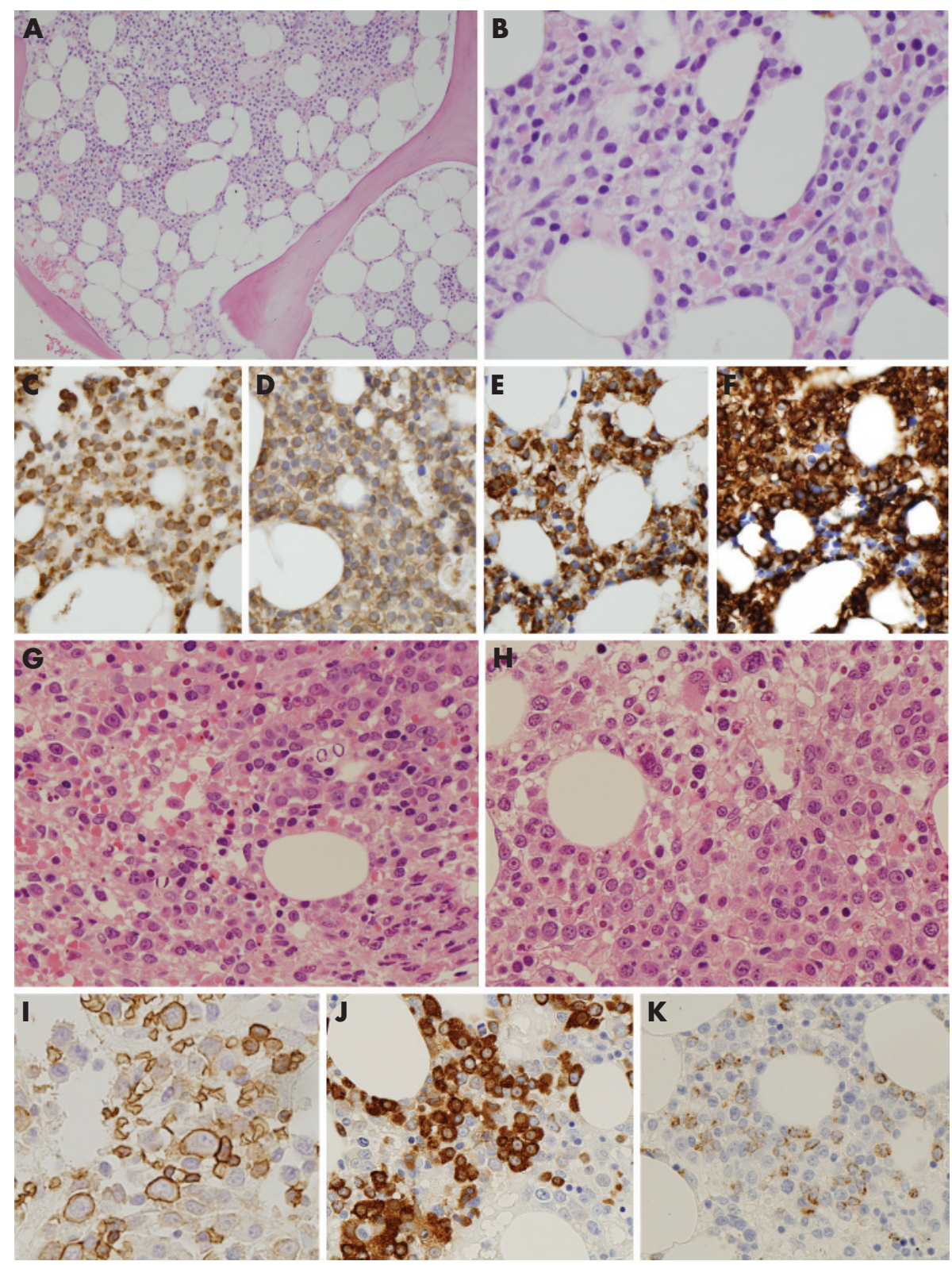

Figure 2 (A-F) Hairy-cell leukaemia, haematoxylin and eosin (H\&E) staining (A) $\times 40$; (B) $\times 200$; (C) TRAP, $\times 200$; (D) CD25, $\times 200$; (E) DBA44, $\times 200$; (F) CD20, $\times 200$. (G-K) Myelodysplastic syndrome (refractory anaemia with excess blasts), H\&E staining (G) $\times 100$; (H) $\times 200$; (I) glycophorin C, $\times 200$; (J) myeloperoxidase, $\times 200$; (K) CD34, $\times 200$.

semithin sections and be suitable for a wide range of immunohistochemical staining. With this purpose, we embarked on AZF fixative, which is formalin based and contains the nuclear mordant zinc. We are able to cut $1-\mu \mathrm{m}$ thick sections providing excellent morphology (fig 1). To hasten the decalcification process, we use a short period of formic acid decalcification.

EDTA, which is widely used for processing of BMT specimens, is slow and takes a minimum of $24 \mathrm{~h}$ (although application of an ultrasonic bath can help hasten this process). ${ }^{11}$ Although some laboratories report better success at DNA amplification on samples decalcified with EDTA, this is variable. ${ }^{12}$ On the other hand, acid decalcification with hydrochloric acid, nitric acid or formic acid is faster, but is believed to result in some destruction of antigens and tissue architecture. Short periods of acid decalcification, however, do not seem to have a deleterious effect on molecular diagnostics, including fluorescence in situ hybridisation and comparative genomic hybridisation studies. ${ }^{13} 14$

To obtain better morphology, fixatives like Bouin's, mercury-containing solutions such as Zenker's fixative and B5 have been used. Some of these are, however, said to have a deleterious effect on preservation of antigens and nucleic acids, and mercurial fixatives pose problems related to disposal. ${ }^{15}{ }^{16}$ Although the morphology is not comparable to that of semithin sections, formalin fixation provides superior antigen and DNA preservation as compared with picric acid or mercury-based fixative. ${ }^{16-18}$ Furthermore, formalin-fixed trephine sections provide adequate RNA preservation as seen in the few published studies on mRNA ISH. ${ }^{19}{ }^{20}$ Thus, formalin fixation seems to be a good "compromise" fixative for processing of BMT specimens. The main criticism has been the suboptimal morphology as compared with resinembedded sections. 
Zinc-containing fixatives have been reported to be superior to formalin in terms of antigen preservation for immunohistochemistry and the recent study by Bonds et al ${ }^{4}$ clearly shows the superiority of AZF over other fixatives for preservation of morphology, antigens, RNA and DNA. ${ }^{41}$

The mechanism by which zinc interacts with proteins and nucleic acids is unclear and is currently part of our research programme in Imperial College. Formalin seems to be necessary for optimal morphology as our modified zinc-based fixative (Z7) still results in some tissue shrinkage, but is compensated for by much improved protein and nucleic acid integrity.

\section{Histochemical and immunohistochemical profiling and molecular diagnostics}

In our hands, sections from AZF-fixed paraffin-waxembedded BMT specimens are optimal for Giemsa, silver and Perl's stains (fig 1 ). The process of decalcification reduces the amount of stainable iron in BMT specimens. Previous studies have reported that processing of BMT specimens with zinc-formalin fixative and formic acid decalcification results in an underestimation of marrow iron. It is only in undecalcified material with plastic sections that ring sideroblasts are easily identified. ${ }^{22} 23$

Because of the nature of BMT samples received at the Hammersmith Hospital (predominantly neoplastic) and treatment or management policies, we use immunohistochemical analysis on most cases (fig 2). Table 1 provides the details of the antibodies we use on BMT specimens. In suspected cases of myeloproliferative disorders and myelodysplastic syndromes, we routinely carry out CD34, CD117, ret40f, myeloperoxidase and CD42b/CD61. This helps us quantify the precursor cell population, identify foci of abnormal localisation of immature precursor cells and identify subtle dysplastic features in the various lineages, including identification of micromegakaryocytes. ${ }^{24-26}$ In addition, cases of systemic mastocytosis are immunostained for mast cell tryptase, CD25 and CD2. ${ }^{27}{ }^{28}$ Cases of suspected acute leukaemia are investigated on a panel of antibodies that includes CD34, TdT, HLA-DR, CD99, myeloperoxidase, CD117, CD68 (KP-1 and PG-M1), ret40f, CD61/CD42b, CD20, CD79a, CD3 and CD10. ${ }^{69-34}$ As well as helping in the proper classification of these cases, documentation of the leukaemia immunophenotype is of utmost importance in evaluating follow-up BMT specimens for response to treatment, residual disease and early relapse.

On BMT specimens taken for staging histologically documented B cell non-Hodgkin's lymphoma, we use a limited panel for immunohistochemistry-CD20, CD3 and CD79a. ${ }^{35}$ In cases of patients with B cell non-Hodgkin's lymphoma who have received anti-CD20 treatment, immunostaining with CD20 is unreliable and may even be negative in residual B cell lymphoma cells. In such cases, CD79a is valuable in identifying residual lymphoma. For staging BMT specimens in patients with anaplastic large-cell lymphomas, the panel includes CD20, CD3, CD30, ALK, epithelial membrane antigen and Pax $-5 .{ }^{36}$ The panel for staging BMT specimens of other node-based peripheral $\mathrm{T}$ cell lymphomas includes CD3, CD20, CD4, CD8, CD30, CD10 and CD21. ${ }^{67} \mathrm{In}$ BMT specimens taken for staging Hodgkin's lymphoma and in those where involvement is suspected on the H\&E stain, the panel includes CD20, CD3, CD15 and CD30. In difficult cases, an extended panel is required.

BMT specimens taken from patients with a clinical diagnosis of $\mathrm{B}$ cell chronic lymphoproliferative disorders, depending on the likely diagnosis, are evaluated for expression of CD20, CD3, CD79a, CD5, CD10, CD21, CD23, CD25, CD43, CD38, CD138, cyclin D1, bcl-2, bcl-6, Pax-5, DBA44, TRAP, and immunoglobulin heavy and light chains. ${ }^{68-44}$ In patients with suspected T cell lymphoproliferative disorders, depending on the likely diagnosis, BMT specimens are evaluated for expression of CD2, CD3, CD5, CD7, CD4, CD8, CD20, CD56, CD57, cytotoxic molecules, CD30 and TCR $\beta .^{6}{ }^{45}$

In patients with suspected clonal plasma cell proliferations, BMT specimens are evaluated for expression of CD20, CD79a, CD3, CD138, vs38C, CD56, cyclin D1, epithelial membrane antigen and immunoglobulin light chains and, in some cases, heavy chains. ${ }^{6}$ Documenting the phenotype of myeloma cells in each case, in our experience, has been extremely valuable in evaluating follow-up samples for residual disease. The immunohistochemistry panel in BMT specimens evaluated for metastatic disease and histiocytic proliferations would depend on histological evaluation of the H\&E section.

For the purposes of research, we have carried out double immunostains with antibodies to ret40f, CD61, Ki-67 and Mcm-2 on a good number of BMT specimens with very good results (fig 3 ). ${ }^{46}$

Over the past 6 months, we have been carrying out ISH analysis of mRNA for $\kappa$ and $\lambda$ light chains and of EBVencoded small RNA-1 for EBV. The results have been good and mRNA preservation has been more than satisfactory (fig 4). Although there have been many studies investigating clonality in lymphoid or plasma cell proliferations with mRNA-ISH for immunoglobulin light chains, only a few of the published studies have been on BMT specimens. ${ }^{47-49}$ Generally, immunostaining for light chains is adequate. In BMT samples, however, in cases which have abundant background staining owing to adsorbed immunoglobulin in the background tissues, ISH results are often cleaner and much easier to interpret. Few studies relating to ISH for EBV on BMTs exist. These can be of great value in identifying bone marrow involvement by EBV-associated lymphoid malignancies such as $\mathrm{T}$ cell or natural killer cell lymphomas and Hodgkin's lymphoma. ${ }^{50}$ Although cells expressing CD30 or CD3 or other tumour cell-marking antigens would not be restricted to the tumour cell population in the marrow sample, EBV would almost be restricted to tumour cells. ISH for EBV-encoded small RNA-1 is more useful than immunostaining for EBV-LMP-1 as it is more sensitive and is expressed across all types of EBV latency. ${ }^{51}$ The strategy would be very valuable in evaluating bone marrow samples from patients with HIV in whom 100\% of cases of Hodgkin's lymphoma are EBV associated and the bone marrow is affected in a large proportion of patients. In our experience and that of others, bone marrow may often be the initial site of disease presentation. ${ }^{52}$

More recently, we extracted DNA from BMT specimens processed by our protocol for the purposes of PCR amplification. We carried out PCR analysis for immunoglobulin gene heavy-chain rearrangement on a few samples (fig 5). We

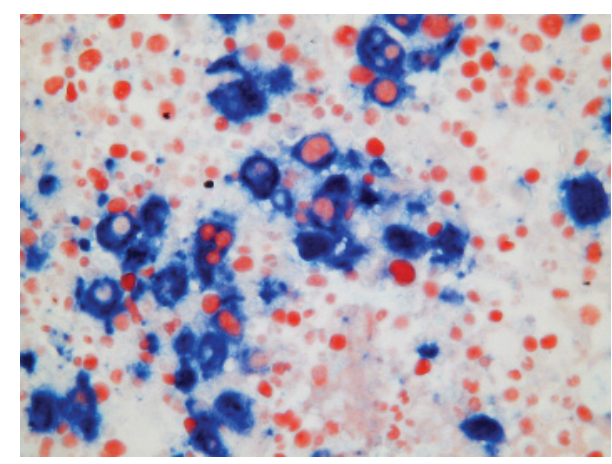

Figure 3 Myeloproliferative disorder; $\mathrm{Mcm}-2$ in nucleus (red) and CD61 in cytoplasm of megakaryocytes (blue; $\times 400$ ). The figure has been contributed by $\mathrm{Dr} I$ Lampert and is part of his ongoing research. 

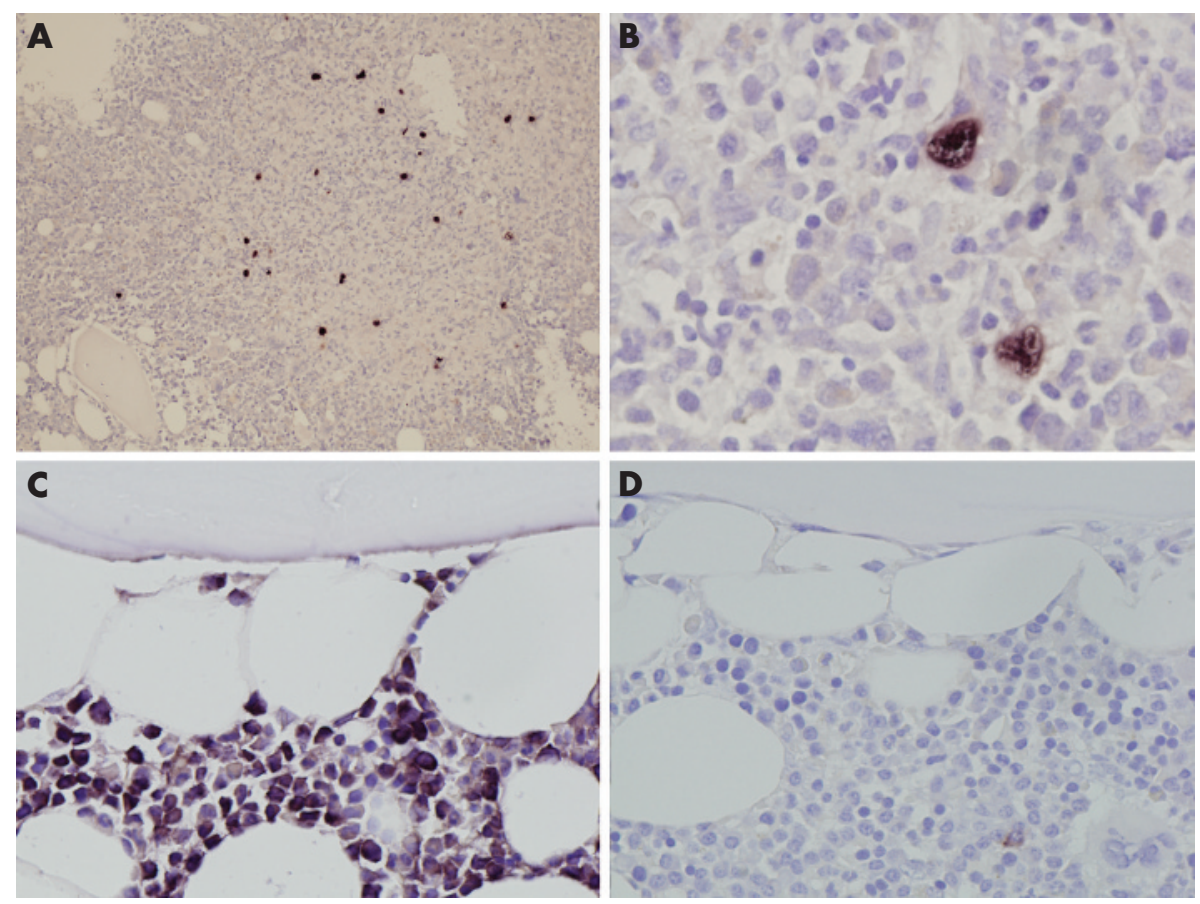

Figure 4 (A,B) mRNA in situ hybridisation (ISH) with Epstein-Barr virus-encoded small RNA-1 probe in a case of Hodgkin's lymphoma focally affecting the bone marrow (A) $\times 100 ;(D) \times 400$. (C,D) mRNA-ISH with $\kappa$ and $\lambda$ light chain probes in a case of myeloma: (C) $\kappa, \times 200 ;(D) \lambda, \times 200$.

need to study cases for a wider array of PCR-based molecular diagnostics and analyse a large number of samples. Although many investigators find formalin-fixed, EDTA-decalcified paraffin-wax-embedded BMT specimens to be adequate for molecular diagnostics, the preservation of DNA has been previously reported to be superior with zinc-based fixatives compared with formalin..$^{53}$

\section{Laboratory integration and turnaround time}

We aimed at making a protocol that would be quick, so as not to hamper the turnaround time and at the same time include procedures that would generally be similar to other tissue processing protocols in the laboratory. The H\&E-stained section with Giemsa, reticulin and Perl's and the initial panel of immunostains is ready in $72 \mathrm{~h}$ of receipt of BMT samples. The H\&E-stained section and the sections stained with histochemical stains are available in $48 \mathrm{~h}$, if there is a need for urgent or provisional report (table 2).

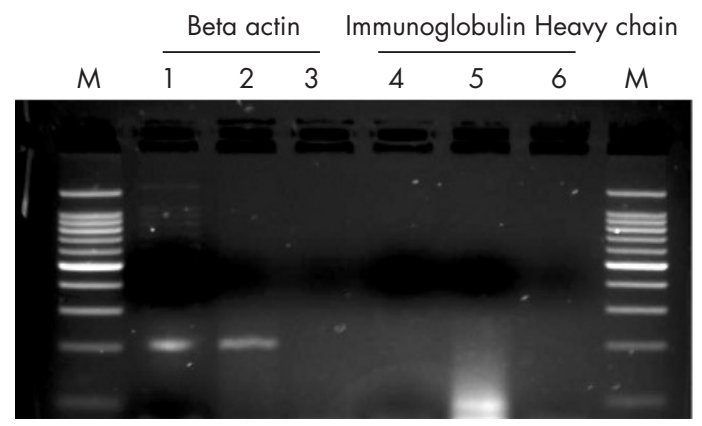

$200 \mathrm{bp}$ $100 \mathrm{bp}$

Figure 5 PCR with DNA extracted from bone marrow trephine (BMT) specimens. Lanes 1 and 4, a BMT specimen with no evidence of neoplastic disease. Lanes 2 and 5, a BMT specimen heavily affected by chronic lymphocytic leukaemia. Lanes 3 and 6 , water control. Lanes 1-3, PCR analysis with primers for $\beta$-actin gene. Lanes 4-6, PCR analysis with FR3 and JH primers for identification of immunoglobulin heavy chain gene rearrangement. $M$, DNA marker.
It should be emphasised that thin sectioning, preferably by an experienced histotechnologist, is a key variable in ensuring excellent slides from which a maximal amount of diagnostic information can be extracted.

\section{Affordability and toxicity}

The costs of the reagents and their disposal are comparable with standard approaches and are considerably cheaper than resin-embedding techniques. The AZF fixative is less toxic than many "special" fixatives and on a par with formalin. One of the major advantages is that the processing is similar to that of a non-osseous biopsy specimen and can be incorporated into the routine laboratory schedules.

\section{CONCLUSIONS}

Although we find that our method works very well at the Hammersmith Hospital, the ideal method for handling BMT specimens should be worked out at each institution. Variables to be considered are the ability to provide haematologists with special fixatives, the costs of fixatives (and the disposal thereof) and special processing such as

Table 2 Turnaround time for bone marrow trephine biopsy specimens including first panel of immunohistochemistry

\begin{tabular}{llll}
\hline & Procedure & Time (h) & $\begin{array}{l}\text { Procedure } \\
\text { completion on day }\end{array}$ \\
\hline 1 & $\begin{array}{l}\text { Fixation } \\
2\end{array}$ & $20-24$ & 1 \\
3 & $\begin{array}{l}\text { Decalcification } \\
\text { Processing and embedding }\end{array}$ & 6 & 1 \\
4 & $\begin{array}{l}\text { Sectioning for haematoxylin } \\
\text { and eosin, special stains and }\end{array}$ & 1 & 2 \\
$\quad \begin{array}{l}\text { first panel of immunostains } \\
\text { Staining procedures including } \\
\text { first panel of immunostains }\end{array}$ & 6 & 2 \\
\hline
\end{tabular}




\section{Take-home messages}

- The Hammersmith Protocol provides a comprehensive approach to handle and investigate bone marrow trephine biopsy samples with an intent to aid and affect management of haematological conditions, especially haematological malignancies.

- The protocol provides excellent morphology, optimal antigen preservation for a complete array of immunohistochemistry and nucleic acid preservation for PCR and mRNA in situ hybridisation-based studies.

- Morphology is comparable to plastic sections as $1-\mu \mathrm{m}$ thin sections can be made.

- The protocol can be used in a routine histopathology setup and does not require any specialised equipment.

- The protocol provides a fast turnaround time with results of haematoxylin and eosin and other histochemical stains being available in $48 \mathrm{~h}$ and those of other immunostains being available in $72 \mathrm{~h}$ of carrying out the biopsy.

resin embedding, the requirement for rapid generation of diagnostic slides to speed turnaround time, the experience of the histotechnologists and the need for molecular studies on the types of trephine biopsy specimens obtained at that institution. In addition, different fixation and decalcification methods may have variable success in interacting with different types of tissue processors, antigen-retrieval methods and immunohistochemistry methods. We believe that, with minimal adaptations to suit minor differences in general tissue processing among different histopathology laboratories, the Hammersmith protocol described in this communication can be easily standardised and maintained in any laboratory. This method provides excellent morphology and immunohistochemistry results. In addition, the method is also optimal for preservation of nucleic acids, both DNA and RNA, for molecular diagnostics and ISH-based studies.

\section{Authors' affiliations}

K N Naresh, I Lampert, R Hasseriian, D Lykidis, K Elderfield, D Horncastle, N Smith, W Murray-Brown, G W Stamp, Department of Histopathology, Hammersmith Hospital, London, UK

Competing interests: None declared.

\section{REFERENCES}

1 Loyson SA, Rademakers LH, Joling P, et al. Immunohistochemical analysis of decalcified paraffin-embedded human bone marrow biopsies with emphasis on MHC class I and CD34 expression. Histopathology 1997;31:412-9.

2 Gatter KC, Heryet A, Brown DC, et al. Is it necessary to embed bone marrow biopsies in plastic for haematological diagnosis? Histopathology 1987; 11:1-7.

3 Mullink H, Henzen-Logmans SC, Tadema TM, et al. Influence of fixation and decalcification on the immunohistochemical staining of cell-specific markers in paraffin-embedded human bone biopsies. J Histochem Cytochem 1985;33:1103-9

4 Bonds LA, Barnes P, Foucar K, et al. Acetic acid-zinc-formalin: a safe alternative to B-5 fixative. Am J Clin Pathol 2005; 124:205-11.

5 Lan HY, Wei M, Nikolic-Paterson DJ, et al. A novel, simple, reliable and sensitive method for multiple immunoenzyme staining: use of microwave oven heating to block antibody crossreactivity and retrieve antigens. J Histochem Cytochem 1995;43:97-102

6 Kremer M, Quintanilla-Martinez L, Nahrig J, et al. Immunohistochemistry in bone marrow pathology: a useful adjunct for morphologic diagnosis. Virchows Arch 2005:447:920-37.

7 Krenacs T, Bagdi E, Stelkovics E, et al. How we process trephine biopsy specimens: epoxy resin embedded bone marrow biopsies. J Clin Pathol 2005; 58:897-903
8 Blythe D, Hand NM, Jackson $P$, et al. Use of methyl methacrylate resin for embedding bone marrow trephine biopsy specimens. J Clin Pathol 1997;50:45-9

9 McCluggage WG, Roddy S, Whiteside C, et al. Immunohistochemical staining of plastic embedded bone marrow trephine biopsy specimens after microwave heating. J Clin Pathol 1995;48:840-4.

10 Fend F, Gschwendtner A, Gredler E, et al. Detection of monoclonal B-cell populations in decalcified, plastic-embedded bone marrow biopsies with the polymerase chain reaction. Am J Clin Pathol 1994;102:850-5.

11 Milan L, Trachtenberg MC. Ultrasonic decalcification of bone. Am J Surg Pathol 1981;5:573-9.

12 Wickham CL, Sarsfield P, Joyner MV, et al. Formic acid decalcification of bone marrow trephines degrades DNA: alternative use of EDTA allows the amplification and sequencing of relatively long PCR products. Mol Pathol 2000;53:336.

13 Gebhard S, Benhattar J, Bricod C, et al. Polymerase chain reaction in the diagnosis of T-cell lymphoma in paraffin-embedded bone marrow biopsies: a comparative study. Histopathology 2001;38:37-44.

14 Brown RS, Edwards J, Bartlett JW, et al. Routine acid decalcification of bone marrow samples can preserve DNA for FISH and CGH studies in metastatic prostate cancer. J Histochem Cytochem 2002;50:113-5.

15 Gala JL, Chenut F, Hong KB, et al. A panel of antibodies for the immunostaining of Bouin's fixed bone marrow trephine biopsies. J Clin Pathol 1997; 50:521-4.

16 Nagasaka T, Lai R, Chen YY, et al. The use of archival bone marrow specimens in detecting B-cell non-Hodgkin's lymphomas using polymerase chain reaction methods. Leuk Lymphoma 2000;36:347-52.

17 Werner M, Kaloutsi V, Walter K, et al. Immunohistochemical examination of routinely processed bone marrow biopsies. Pathol Res Pract 1992;188:707-13.

18 Toth B, Wehrmann M, Kaiserling E, et al. Immunophenotyping of acute lymphoblastic leukaemia in routinely processed bone marrow biopsy specimens. J Clin Pathol 1999;52:688-92.

19 Wong KF, Chan JK, Cheung MM, et al. Bone marrow involvement by nasal NK cell lymphoma at diagnosis is uncommon. Am J Clin Pathol $2001 ; 115: 266-70$

20 Roncaroli F, Dina R, Geuna $M$, et al. Identification of granulocytemacrophage colony stimulating factor receptor mRNA by non-isotopic in situ hybridization in bone marrow biopsies. Haematologica 1994:79:322-7.

21 Beckstead JH. A simple technique for preservation of fixation-sensitive antigens in paraffin-embedded tissues. J Histochem Cytochem 1994;42:1127-34

22 DePalma L. The effect of decalcification and choice of fixative on histiocytic iron in bone marrow core biopsies. Biotech Histochem 1996;71:57-60.

23 Stuart-Smith SE, Hughes DA, Bain BJ. Are routine iron stains on bone marrow trephine biopsy specimens necessary? J Clin Pathol 2005;58:269-72.

24 Elliot V. Marin D, Horncastle D, et al. Percentage of CD34 cells in a minimum 500 -cell count in bone marrow trephines of patients with chronic myeloid leukaemia provides the best correlation with aspirate blast count. $\mathrm{Br} J$ Haematol 2005; 130:460-1

25 Naresh KN, Lampert IA. CD 117 Expression as an aid to identify immature myeloid cells and foci of ALIP in bone marrow trephines. Am J Hematol 2006;81:79.

26 Orazi A, Albitar M, Heerema NA, et al. Hypoplastic myelodysplastic syndromes can be distinguished from acquired aplastic anemia by CD34 and PCNA immunostaining of bone marrow biopsy specimens. Am J Clin Pathol 1997; 107:268-74.

27 Sotlar K, Horny HP, Simonitsch I, et al. CD25 indicates the neoplastic phenotype of mast cells: a novel immunohistochemical marker for the diagnosis of systemic mastocytosis (SM) in routinely processed bone marrow biopsy specimens. Am J Surg Pathol 2004;28:1319-25.

28 Valent P, Horny HP, Escribano L, et al. Diagnostic criteria and classification of mastocytosis: a consensus proposal. Leuk Res 2001;25:603-25.

29 Bavikatty NR, Ross CW, Finn WG, et al. Anti-CD10 immunoperoxidase staining of paraffin-embedded acute leukemias: comparison with flow cytometric immunophenotyping. Hum Pathol 2000;31:1051-4.

30 Krober SM, Greschniok A, Kaiserling E, et al. Acute lymphoblastic leukaemia: correlation between morphological/immunohistochemical and molecular biological findings in bone marrow biopsy specimens. Mol Pathol 2000;53:83-7

31 Pileri SA, Ascani S, Milani M, et al. Acute leukaemia immunophenotyping in bone-marrow routine sections. Br J Haematol 1999;105:394-401.

32 Torlakovic $\mathbf{E}$, Torlakovic $\mathrm{G}, \mathrm{Nguyen} \mathrm{PL}$, et al. The value of anti-pax-5 immunostaining in routinely fixed and paraffin-embedded sections: a nove pan pre-B and B-cell marker. Am J Surg Pathol 2002;26:1343-50.

33 Lucas DR, Bentley G, Dan ME, et al. Ewing sarcoma vs lymphoblastic lymphoma. A comparative immunohistochemical study. Am J Clin Pathol 2001;115:11-7.

34 Cascavilla N, Musto P, D'Arena G, et al. CD1 17 (c-kit) is a restricted antigen of acute myeloid leukemia and characterizes early differentiative levels of $M 5$ FAB subtype. Haematologica 1998;83:392-7.

35 Crotty PL, Smith BR, Tallini G. Morphologic, immunophenotypic, and molecular evaluation of bone marrow involvement in non-Hodgkin's lymphoma. Diagn Mol Pathol 1998;7:90-5.

36 Gujral S, Prasad R, Naresh KN. Systemic anaplastic large cell lymphoma in a child presenting with bone marrow involvement and clinical features of acute leukaemia. Am J Hematol 2002;69:150-1.

37 Gaulard P, Kanavaros P, Farcet JP, et al. Bone marrow histologic and immunohistochemical findings in peripheral. T-cell lymphoma: a study of 38 cases. Hum Pathol 1991:22:331-8. 
38 Jilani I, O'Brien S, Manshuri T, et al. Transient down-modulation of CD20 by rituximab in patients with chronic lymphocytic leukemia. Blood 2003:102:3514-20.

39 Schmid C, Isaacson PG. Bone marrow trephine biopsy in lymphoproliferative disease. J Clin Pathol 1992:45:745-50.

40 Andriko JA, Swerdlow SH, Aguilera NI, et al. Is lymphoplasmacytic lymphoma/immunocytoma a distinct entity? A clinicopathologic study of 20 cases. Am J Surg Pathol 2001;25:742-51.

41 Tworek JA, Singleton TP, Schnitzer B, et al. Flow cytometric and immunohistochemical analysis of small lymphocytic lymphoma, mantle cell lymphoma, and plasmacytoid small lymphocytic lymphoma. Am J Clin Pathol 1998; 110:582-9.

42 Franco V, Florena AM, lannitto E. Splenic marginal zone lymphoma. Blood 2003;101:2464-72.

43 Hoyer JD, Li CY, Yam LT, et al. Immunohistochemical demonstration of acid phosphatase isoenzyme 5 (tartrate-resistant) in paraffin sections of hairy cell leukemia and other hematologic disorders. Am J Clin Pathol 1997; 108:308-15.

44 Salomon-Nguyen F, Valensi F, Troussard X, et al. The value of the monoclonal antibody, DBA44, in the diagnosis of B-lymphoid disorders. Leuk Res 1996;20:909-13.

45 Belhadj K, Reyes F, Farcet JP, et al. Hepatosplenic gammadelta T-cell lymphoma is a rare clinicopathologic entity with poor outcome: report on a series of 21 patients. Blood 2003;102:4261-9.

46 Lampert IA, Horncastle D, Dilworth S, et al. The expression of minichromosome maintenance protein-2 in normal and abnormal megakaryocytes and comparison with the proliferative marker $\mathrm{Ki}-67$ Br J Haematol 2005;131:490-4.
47 Beck RC, Tubbs RR, Hussein M, et al. Automated colorimetric in situ hybridization (CISH) detection of immunoglobulin (lg) light chain mRNA expression in plasma cell (PC) dyscrasias and non-Hodgkin lymphoma. Diagn Mol Pathol 2003;12:14-20.

48 Erber WN, Asbahr HD, Phelps PN. In situ hybridization of immunoglobulin light chain mRNA on bone marrow trephines using biotinylated probes and the APAAP method. Pathology 1993;25:63-7.

49 Akhtar N, Ruprai A, Pringle JH, et al. In situ hybridization detection of light chain mRNA in routine bone marrow trephines from patients with suspected myeloma. BrJ Haematol 1989;73:296-301.

50 Hamilton-Dutoit SJ, Raphael M, et al. In situ demonstration of Epstein-Barr virus small RNAs (EBER 1) in acquired immunodeficiency syndrome-related lymphomas: correlation with tumor morphology and primary site. Blood 1993;82:619-24.

51 Naresh KN, Johnson J, Srinivas V, et al. Epstein-Barr virus association in classical Hodgkin's disease provides survival advantage to patients and correlates with higher expression of proliferation markers in Reed-Sternberg cells. Ann Oncol 2000;11:91-6.

52 Ponzoni M, Fumagalli L, Rossi G, et al. Isolated bone marrow manifestation of HIV-associated Hodgkin lymphoma. Mod Pathol 2002; 15:1273-8.

53 Fend F, Bock O, Kremer M, et al. Ancillary techniques in bone marrow pathology: molecular diagnostics on bone marrow trephine biopsies. Virchows Arch 2005;447:909-19.

54 Wester K, Asplund A, Backvall H, et al. Zinc-based fixative improves preservation of genomic DNA and proteins in histoprocessing of human tissues. Lab lnvest 2003;83:889-99. 